\title{
Seasonality in planktic foraminifera of the central California coastal upwelling region
}

\author{
Catherine V. Davis ${ }^{1,2}$, Tessa M. Hill ${ }^{1,2}$, Ann D. Russell ${ }^{2}$, Brian Gaylord ${ }^{1}$, and Jaime Jahncke ${ }^{3}$ \\ ${ }^{1}$ Bodega Marine Laboratory, University of California Davis, Bodega Bay, USA \\ ${ }^{2}$ Department of Earth and Planetary Science, University of California Davis, Davis, USA \\ ${ }^{3}$ Point Blue Conservation Sciences, Petaluma, USA \\ Correspondence to: Catherine V. Davis (cvdavis@ucdavis.edu)
}

Received: 6 December 2015 - Published in Biogeosciences Discuss.: 18 January 2016

Revised: 7 July 2016 - Accepted: 25 August 2016 - Published: 16 September 2016

\begin{abstract}
The close association between planktic foraminiferal assemblages and local hydrography make foraminifera invaluable proxies for environmental conditions. Modern foraminiferal seasonality is important for interpreting fossil distributions and shell geochemistry as paleoclimate proxies. Understanding this seasonality in an active upwelling area is also critical for anticipating which species may be vulnerable to future changes in upwelling intensity and ocean acidification. Two years (2012-2014) of plankton tows, along with conductivity-temperature-depth profiles and carbonate chemistry measurements taken along the north-central California shelf, offer new insights into the seasonal dynamics of planktic foraminifera in a seasonal coastal upwelling regime. This study finds an upwelling affinity for Neogloboquadrina pachyderma as well as a seasonal and upwelling associated alternation between dominance of $N$. pachyderma and Neogloboquadrina incompta, consistent with previous observations. Globigerina bulloides, however, shows a strong affinity for non-upwelled waters, in contrast to findings in Southern California where the species is often associated with upwelling. We also find an apparent lunar periodicity in the abundances of all species and document the presence of foraminifera even at very low saturation states of calcite.
\end{abstract}

\section{Introduction}

Planktic foraminifera have a long history as paleoceanographic proxies due to their environmental sensitivity, cosmopolitan distribution, and extensive fossil record. The close association between planktic species and local hydrography means that fossil foraminiferal assemblages have often been used to reconstruct the distribution of water masses through time (e.g., Berger, 1968; McIntyre et al., 1972; Oberhänsli et al., 1992; Ufkes et al., 1998). However, at sites where overlying water masses change seasonally, the foraminiferal fossil record will represent a combination of individuals that may have grown under vastly different conditions. This averaging of short-term variability has the potential to impact the interpretation of any proxy based on foraminifera. Seasonality in a variety of environments has been shown to have a pronounced effect on foraminiferal communities, with species assemblages changing throughout the year (Thunell et al., 1983; Reynolds and Thunell, 1985; Thunell and Honjo, 1987; Thunell and Sautter, 1992; Ortiz et al., 1995; Marchant et al., 1998; Eguchi et al., 2003; Pak et al., 2004). Previous studies have explored seasonal assemblage shifts in the North Pacific, including at Station Papa $\left(50^{\circ} \mathrm{N}, 145^{\circ} \mathrm{W}\right.$; Thunell and Reynolds, 1984; Reynolds and Thunell, 1985), in the California Current off of Oregon (>130 km offshore) (Ortiz et al., 1995), in the Santa Barbara Basin (Kincaid et al., 2000; Darling et al., 2003), off Southern California (Sautter and Thunnell, 1991), and in the western Pacific (Eguchi et al., 2003). The majority of this prior work has focused on openocean assemblages, however, leaving a gap in understanding the seasonal dynamics in coastal upwelling regions, as well as a significant spatial gap within the California Current system between the Southern California Bight and Oregon.

An improved understanding of coastal upwelling fauna is also important for interpreting the paleoclimate record of these conditions (Reynolds and Thunell, 1986; Naidu and 
Malmgren, 1995; Vénec-Peyré and Caulet, 2000; Ishikawa and Oda, 2007). Many modern surveys have characterized upwelling-associated foraminifera through plankton tow and sediment trap studies in the tropics and subtropics (e.g., Thiede, 1975; Naidu, 1990; Thunell and Sautter, 1992; Pak et al., 2004; Salgueiro et al., 2008). Temperate and subpolar upwelling communities such as those found along the central California shelf, however, remain poorly understood. On-shelf assemblages are particularly important for regions dominated by coastal upwelling processes where the alternation between upwelling and relaxation (periods of reduced wind strength in between upwelling periods) has large regional impacts on oceanography and planktic communities (Botsford et al., 2006; Dugdale et al., 2006; Largier et al., 2006; Garcí-Reyes et al., 2014). From a paleontological perspective, modern nearshore assemblages are of interest because sediments in these regions are among those most likely to contain a preserved carbonate fossil record, and thus intact fossil assemblages, due to the high sedimentation rates and the limitations of a narrow continental shelf above a shallow lysocline.

Understanding planktic foraminiferal assemblages in coastal upwelling regions is also relevant for predicting future climate and ecosystem perturbations. The California Current and other Eastern Boundary Current upwelling systems have been identified as especially susceptible to ocean acidification due to the incorporation of anthropogenic $\mathrm{CO}_{2}$ into the surface ocean superimposed on naturally corrosive waters (Feely et al., 2008; Hofmann et al., 2010; Hauri et al., 2013). The pronounced influence of upwelling in this region is also likely to intensify due to anthropogenic impacts (Bakun, 1990; García-Reyes and Largier, 2012; Sydeman et al., 2014), compounding the impacts of ocean acidification. Planktic calcifiers such as pteropods (Bednaršek et al., 2014; Busch et al., 2014), coccolithophorids (Beaufort et al., 2011; Iglesias-Rodriguez et al., 2008; Langer et al., 2006), and foraminifera (Barker and Elderfield, 2002; Manno et al., 2012; Moy et al., 2009) may be especially vulnerable to reductions in ocean calcite and aragonite saturation state. Upwelled waters are already becoming more acidic along the California margin, and the seasonal duration for which fauna are exposed to waters undersaturated with respect to aragonite and calcite is predicted to increase in the near future (Feely et al., 2008; Gruber et al., 2012; Harris et al., 2013; Hauri et al., 2013). The response of planktic foraminiferal assemblages to 20th century warming has been documented in Southern California (Field et al., 2006). An understanding of the modern seasonality of planktic foraminifera in this intense upwelling region can therefore serve as a baseline for future climate-driven change and may help to identify which upwelling species may already be living at lowsaturation state and be potentially tolerant of low calcite saturate state waters that may resemble future conditions in the open ocean.
Here we focus on planktic foraminiferal assemblages sampled along a cross-shore transect over the central California shelf extending from $1 \mathrm{~km}$ offshore to the shelf break (30$60 \mathrm{~km}$ offshore). Plankton tows, supported by in situ water column data and discrete bottle samples, allow a documentation of species associations based on instantaneous (as opposed to time-averaged) water column conditions. Our goal was to understand (1) the spatial and temporal distribution of planktic foraminifera along the central California shelf and (2) the manner in which species assemblages respond to high frequency changes in water mass, especially those associated with upwelling. These efforts may offer a general framework for interpreting seasonality in foraminiferal records drawn from analogous oceanographic regions and could yield new insights into how this important group of marine calcifiers responds to ongoing climate change and acidification in coastal upwelling systems.

\section{Regional setting}

The California Current is the southward flowing arm of the North Pacific Subtropical Gyre and, along with the seasonal Davidson Countercurrent, flows adjacent to the central Californian coastline to the west of our study sites. At many locations along the coast, wind-driven coastal upwelling brings deeper, colder, nutrient-rich and low- $\mathrm{O}_{2}$ water to the surface, with the strongest upwelling signal found in a 10 to $25 \mathrm{~km}$ band just offshore (Hickey, 1979, 1979; Huyer, 1983; Lynn and Simpson, 1987).

At the latitudes of our study sites $\left(37-39^{\circ} \mathrm{N}\right)$, winddriven coastal upwelling is generally strongest in April-June (García-Reyes and Largier, 2012). During the upwelling season, wind-driven upwelling events are interspersed with relaxation periods, the combination of which is responsible for large changes in productivity in the plankton (Botsford et al., 2006; Dugdale et al., 2006; Largier et al., 2006; García-Reyes et al., 2014). During the upwelling season, further complexity is introduced through the advection of upwelled water masses both away from the continent and alongshore, with water parcels in the region which are dominantly sourced from the north (Kaplan and Largier, 2006). Outside of the upwelling season ( $\sim$ September-March), upwelling events are generally absent and there is occasional occurrence of downwelling, with net northward flow of water. Advection rates are variable but have been reported in the range of $10-30 \mathrm{~km} \mathrm{~d}^{-1}$ (Kaplan and Largier, 2006). This stable postupwelling season generally lasts into December when the stability can be punctuated by storm conditions (Kaplan and Largier, 2006; García-Reyes and Largier, 2012). Together, these conditions create an environment of strong seasonality in terms of productivity, temperature, $\mathrm{O}_{2}$, carbon chemistry, and water mass, all of which would be expected to influence the species of planktic foraminifera present in the region. 
Table 1. Station locations, depths, and the number of times sampled over the course of this study.

\begin{tabular}{lllrr}
\hline Station & Latitude & Longitude & $\begin{array}{r}\text { Depth } \\
\text { sampled (m) }\end{array}$ & $\begin{array}{r}\text { No. of times } \\
\text { sampled }\end{array}$ \\
\hline BL1 & $38^{\circ} 16^{\prime} 59^{\prime \prime}$ & $-123^{\circ} 04^{\prime} 60^{\prime \prime}$ & 25 & 15 \\
BL2 & $38^{\circ} 23^{\prime} 38^{\prime \prime}$ & $-123^{\circ} 13^{\prime} 00^{\prime \prime}$ & 45 & 15 \\
BL3 & $38^{\circ} 21^{\prime} 05^{\prime \prime}$ & $-123^{\circ} 14^{\prime} 20^{\prime \prime}$ & 90 & 15 \\
BL4 & $38^{\circ} 26^{\prime} 20^{\prime \prime}$ & $-123^{\circ} 27^{\prime} 01^{\prime \prime}$ & 120 & 15 \\
BL5 & $38^{\circ} 21^{\prime} 05^{\prime \prime}$ & $-123^{\circ} 37^{\prime} 59^{\prime \prime}$ & 200 & 14 \\
A2W & $38^{\circ} 02^{\prime} 45^{\prime \prime}$ & $-123^{\circ} 33^{\prime} 47^{\prime \prime}$ & 200 & 5 \\
A4W & $37^{\circ} 52^{\prime} 55^{\prime \prime}$ & $-123^{\circ} 28^{\prime} 30^{\prime \prime}$ & 200 & 4 \\
A6W & $37^{\circ} 43^{\prime} 20^{\prime \prime}$ & $-123^{\circ} 13^{\prime} 59^{\prime \prime}$ & 200 & 5 \\
\hline
\end{tabular}

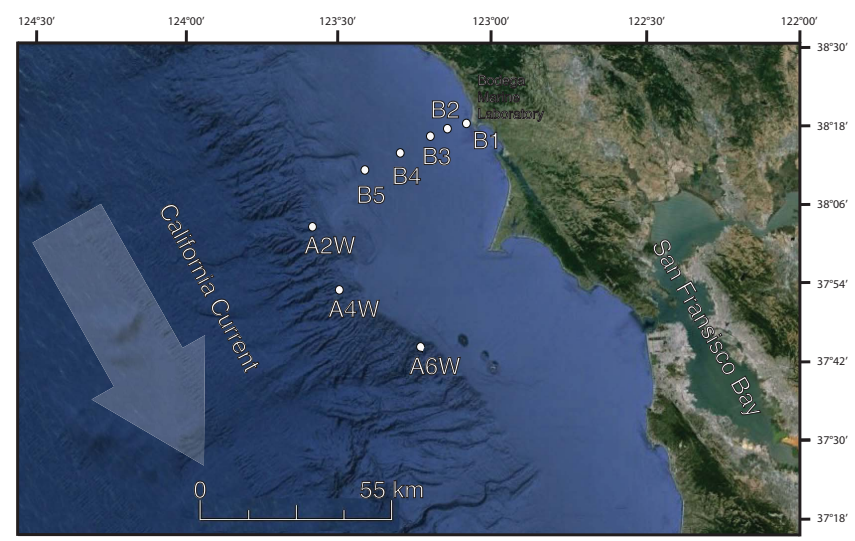

Figure 1. Map of tow stations BL1-5, A2W, A4W, and A6W.

\section{Methods}

\subsection{Study area}

Plankton collection took place at eight stations located at increasing distances from shore across the continental shelf (Fig. 1). Bodega Line (BL) $\left(38^{\circ}\right)$ sites start at nearshore station BL1, $1 \mathrm{~km}$ offshore, and extend across the shelf to station BL5, $32 \mathrm{~km}$ offshore. These stations were sampled monthly to bimonthly from September 2012 to September 2014. Three additional stations were sampled in 2013 and 2014 as part of the Applied California Current Ecosystem Studies (ACCESS) cruises (three times per year) and are located just over the shelf break at $40-60 \mathrm{~km}$ offshore, spanning a latitudinal range from $37-39^{\circ} \mathrm{N}$ (Table 1). All sampling stations are shoreward of the central core of the California Current (Lynn and Simpson, 1987) and are strongly influenced by both spring/summer upwelling as well as winter storms (Fig. 1).

\subsection{Sample collection}

Vertical net tows integrated foraminifera across the water column from the surface to a depth of $200 \mathrm{~m}$ or to $10 \mathrm{~m}$ above the sea floor at shallower sites. All foraminifera were sampled with a $150 \mu \mathrm{m}$ mesh net. This approach po- tentially excludes juveniles and small adults and therefore limited the samples to foraminifera of readily identifiable adult developmental stages and to species normally included in fossil analyses. Most samples were placed in ambient surface seawater and kept chilled without further preservation to be picked immediately upon return to shore. When this procedure was not feasible, samples were preserved shipboard in $95 \%$ ethanol, buffered to a $\mathrm{pH}>8.5$ with Tris(hydroxymethyl)aminomethane. Foraminifera were picked wet from bulk tow material, rinsed in DI water and archived in slides. All archived foraminifera were identified to the lowest possible taxonomic level, with $N$. incompta and $N$. pachyderma defined primarily by shell coiling direction (following Darling et al., 2006). No distinction was made between living and dead individuals although almost all shells still contained some cytoplasm at the time of sorting. Taking into account the conservative end of the range of sinking rates for shells (e.g., 29-552 $\mathrm{m} \mathrm{d}^{-1}$; Takahashi and Be, 1984) and that foraminifera were sampled from the upper $200 \mathrm{~m}$ of the water column, we can assume that all foraminifera were likely alive within 6 days of collection. Transport data from the region allow us to further estimate a maximum horizontal transport of $50 \mathrm{~km}$ in 5 days, indicating that all shells still within the water column were locally sourced (Kaplan and Largier, 2006).

\subsection{Environmental measurements}

Water column profiles for temperature, salinity, dissolved $\mathrm{O}_{2}$ (DO), and fluorescence were obtained across the plankton tow depths using a Seabird Electronics SBE 19 conductivitytemperature-depth (CTD) profiler. Plankton tow nets were equipped with a flow meter for each cast; however, due to frequent failures, flow rates were unreliable and are not reported here. At each station, discrete bottle samples of surface water and water from the bottom of each CTD cast were collected using a Niskin sampler. All water samples were analyzed spectrophotometrically for $\mathrm{pH}$ (total scale) using either a Sunburst SAMI (Submersible Autonomous Moored Instrument) modified for benchtop use $(\mathrm{SD} \pm 0.009)$ or an Ocean Optics Jaz Spectrophotometer EL200 (SD \pm 0.003 ) using $m$-cresol purple (Dickson et al., 2007). Total alkalinity was determined via automated Gran titration on a Metrohm 809 Titrando $\left(\mathrm{SD} \pm 2.809 \mu \mathrm{mol} \mathrm{kg}{ }^{-1}\right.$ ), with acid concentrations standardized to Dickson certified reference materials (A. Dickson, Scripps Institution of Oceanography, CA, USA). Measurements of $\mathrm{pH}$ and alkalinity were carried out at UC Davis Bodega Marine Laboratory and used to calculate other inorganic carbon system parameters, including

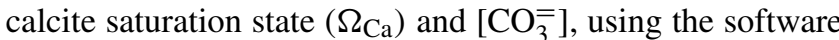
$\mathrm{CO}_{2}$ Calc (Robbins et al., 2010). Thermocline depths were defined as the depth (below $5 \mathrm{~m}$ ) at which the greatest gradient in temperature occurred, exclusive of any temperature change with a slope of less than $0.1{ }^{\circ} \mathrm{Cm}^{-1}$, in which case the thermocline was assumed to be deeper than the profiled 
water. Upwelling index is taken from the PFEL upwelling index modeled for $39^{\circ} \mathrm{N}$ (http://www.pfeg.noaa.gov/products/ PFEL/modeled/indices/upwelling/upwelling.html), which is in general agreement with temperature measurements from the Bodega Ocean Observing Node (BL1).

\subsection{Data analysis}

For the four most abundant species, G. bulloides, Turborotalia quinqueloba, N. incompta, and N. pachyderma, we performed a CCA (canonical correspondence analysis) on relative abundances using the "vegan" package in R (R Core Team, 2013; Oksanen et al., 2016). Potential explanatory variables included day of the lunar cycle relative to the new moon, upwelling index, duration of sustained upwelling as indicated by the PFEL upwelling index, surface and deep water carbonate system parameters, and CTD temperature, salinity, fluorescence, and DO. CTD data were binned into depths at $5 \mathrm{~m}$ intervals to a depth of $25 \mathrm{~m}$ and then at $10 \mathrm{~m}$ intervals. A subset of variables was selected for CCA by exclusion of all variables not related to any total abundances by pairwise correlation at a $95 \%$ confidence level. Strongly interrelated or redundant parameters were additionally excluded (i.e., a parameter correlated at multiple consecutive depths would have been considered at only one of these depths).

\section{Results}

The assemblage was heavily dominated by the planktic species N. pachyderma, N. incompta, T. quinqueloba, and $G$. bulloides, representing 35.3, 23.1, 13.5, and $11.7 \%$ of all recovered foraminifera, respectively. Less common forms included Globigerinita glutinata, Globorotaloides hexagonus, Globigerinella calida, Globigerinita uvula, and Globorotalia spp., as well the occasional cosmopolitan species, Orbulina universa and subtropical Neogloboquadrina dutertrei, and, rarely, benthic species of foraminifera. The presence of these latter taxa was sporadic and in low abundance (all $<1 \%$ of the overall recovered foraminifera, with the exception of G. glutinata at $2.1 \%$ ); therefore, further analysis will be confined to the four most abundant species.

At offshore stations BL3, BL4, and BL5 and off-shelf stations $\mathrm{A} 2 \mathrm{~W}, \mathrm{~A} 4 \mathrm{~W}$, and $\mathrm{A} 6 \mathrm{~W}$, foraminifera displayed a clear seasonality. The year can be divided between spring / summer and fall / winter faunas that coincide with the upwelling-dominated and non-upwelling season (Fig. 2). Beginning in May, shortly after the onset of upwelling, samples began to show a high abundance of T. quinqueloba. A bloom of N. pachyderma, seen here as an increase in total abundance to $>200$ individuals, occurs in July or August, after several months of sustained upwelling, followed by a decrease in both total and relative abundance to less than $50 \%$ by the end of summer (Fig. 3). N. pachyderma was
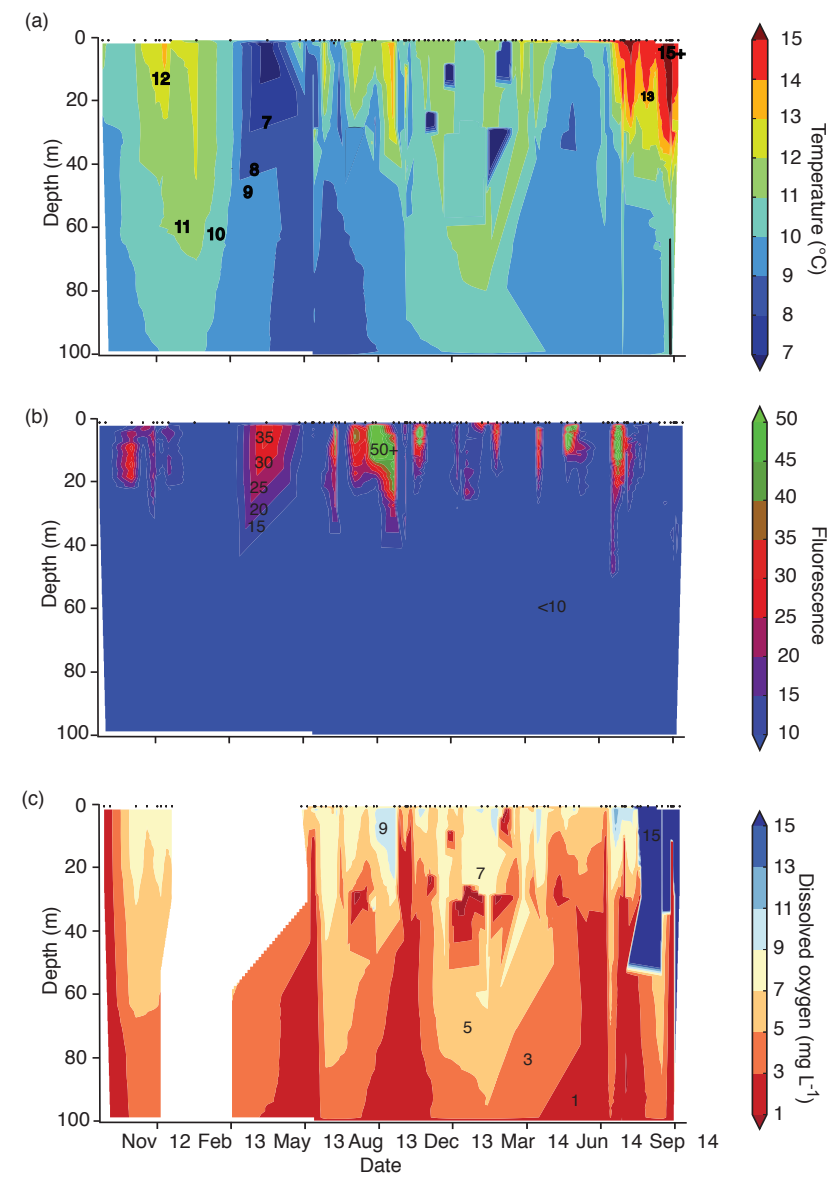

Figure 2. A time series of CTD cast profiles for (a) temperature, (b) productivity, and (c) DO taken between September 2012 and October 2014. Time series are compiled from CTD casts at BL5 in conjunction with plankton tows and supplemented with data from weekly CTD casts taken at BL1 as a part of the Bodega Ocean Observing Node. Black points at the top of each figure denote the location of each CTD cast.

also present through much of the winter in lower numbers in 2012-2013. By contrast, this species was virtually absent in the winter of 2013-2014, before reappearing after a period of sustained upwelling in July 2014 (Fig. 3). In both years, the earliest $N$. pachyderma blooms appeared to initiate farther offshore, although abundances within a given samples did not appear to be directly linked to specific upwelling events.

Following the end of the summer season, the fall-winter fauna shows a more even distribution of species and a distinct shift in the ratio of $N$. pachyderma to $N$. incompta (Fig. 3). N. incompta was equally or more abundant than $N$. pachyderma during the non-upwelling season although it was present year-round. G. bulloides also began to appear in the water column in the fall, strongly associated with nonupwelled waters, and is present throughout the winters. $G$. bulloides was present primarily in the winter and either ab- 

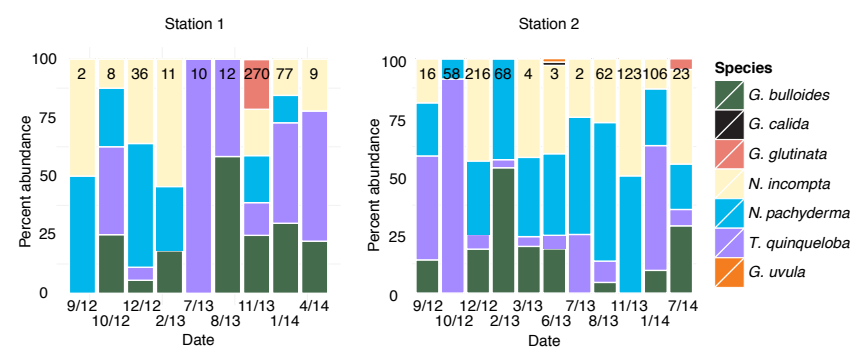

Figure 3. Relative abundance of all species at nearshore stations BL1 and BL2, with total number of foraminifera marked at the top of each bar.

sent or found only in very low numbers during the summer season.

The same suite of species was present at nearshore stations BL1 and BL2, but counts were lower year-round and most seasonal patterns seen offshore were not evident. $N$. pachyderma did appear to increase in relative abundance during the summer at these stations but remained in low abundance along with $N$. incompta year-round (Fig. 4). T. quinqueloba was also observed year-round at these nearshore stations. A greater proportional abundance of G. bulloides was seen during the fall and winter at nearshore sites, consistent with findings at the offshore stations (Fig. 4).

\subsection{Environmental measurements}

In spring and summer, surface hydrographic conditions were highly variable, reflecting alternating upwelling events and relaxation periods. Frequent changes in thermocline depth were observed, as well as intermittent blooms of nearsurface productivity (Fig. 2). This resulted in a more surfacestratified and productive water column, with a shallow thermocline and high fluorescence in the upper water column. During upwelling season, near-surface temperatures cool to $8-9{ }^{\circ} \mathrm{C}$, and subsurface waters approach calcite undersaturation $\left(\Omega_{\mathrm{Ca}}<1\right)$ and display low DO $\left(<4 \mathrm{mg} \mathrm{L}^{-1}\right.$ at $\left.<90 \mathrm{~m}\right)$ (Fig. 5). Despite consistently lower subsurface DO and pH, high near-surface productivity often increased DO and $\mathrm{pH}$ near-surface values, creating a noticeable down-profile gradient in these parameters.

Beginning in the late fall, and continuing into early spring, a consistently deep thermocline was observed at all stations. This trend often had the effect of confining the entire onshelf water column (including all tow samples) to this deep mixed layer, which dominated the shelf in winter. Temperatures were generally warmer $\left(11-14^{\circ} \mathrm{C}\right)$ than during the upwelling season with relatively low fluorescence in the upper water column (<4) (Fig. 5) and $\Omega_{\mathrm{Ca}}>1.5$ throughout the sampled water column. García-Reyes and Largier (2012) describe storm conditions, which are likely to have contributed to the deep mixed layer, observed outside of upwelling season (especially between January and March).

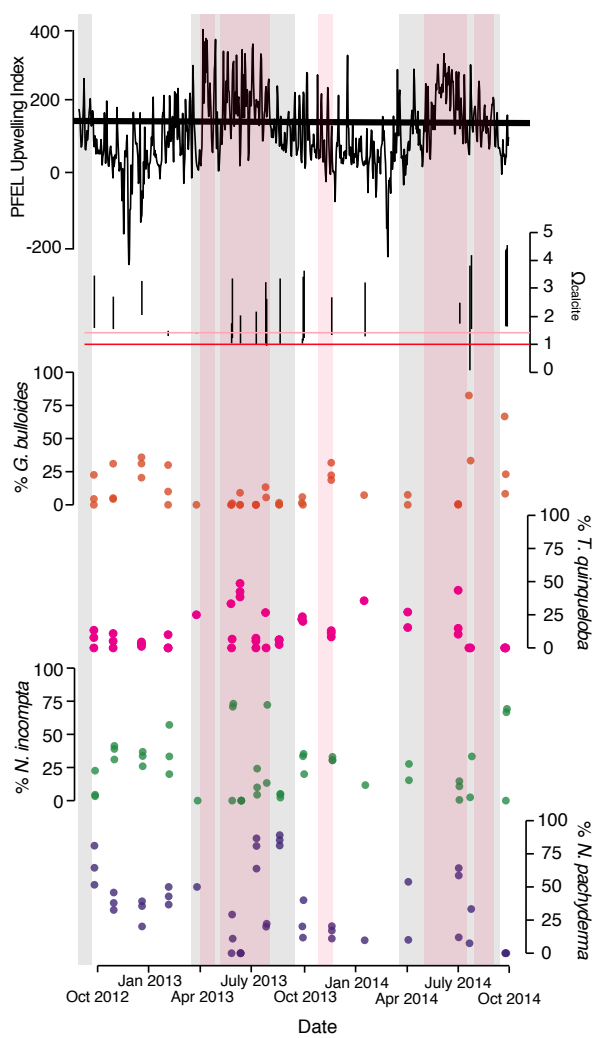

Figure 4. Upwelling index for $39^{\circ} \mathrm{N}$ (PFEL; http://www.pfeg.noaa. gov/products/PFEL/modeled/indices/upwelling/upwelling.html), ), with "upwelling season" shaded in grey and periods of sustained upwelling conditions during the relevant years shaded in red. The range of $C_{\text {alcite }}$ observed on each tow is marked in black, with $\Omega_{\text {calcite }}=1$ marked in red and $\Omega_{\text {calcite }}=1.5$ in pink. Percent abundances from vertical tows of $G$. bulloides, T. quinqueloba, $N$. incompta, and N. pachyderma from offshore stations BL3, BL4, BL5, and off-shelf stations AW2, AW4, and AW6 shown in orange, pink, green, and purple, respectively.

\subsection{Canonical correspondence analysis}

A CCA shows that the highest relative abundances of both G. bulloides and N. incompta fall along dimensions strongly influenced by environmental variables characteristic of nonupwelling season, such as higher temperatures and increased dissolved oxygen. The highest relative abundances of $N$. pachyderma are most closely associated with fluorescence, especially near the surface $(5 \mathrm{~m})$ and at $60-70 \mathrm{~m}$ water depth, more associated with upwelling waters. T. quinqueloba is also distinct, falling within the quadrant most associated with tows taken during upwelling (Fig. 6). Figure 5 additionally shows the range of environmental conditions captured by sampling around the full moon (lunar days 14-18). 


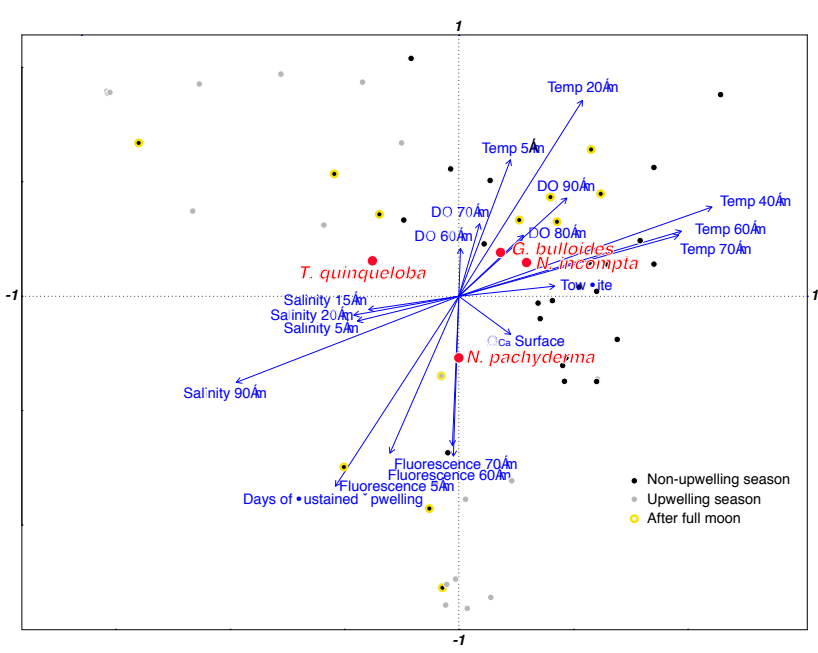

Figure 5. Biplot of canonical correspondence analysis of relative abundance of the four most abundant species compared with environmental variables at the time of collection for all tows in which foraminifera were found. Dominant species are represented by large red points, and small points represent individual tows. Grey points are tows that fall within upwelling season, as shown in Fig. 2, and black points outside of this season. Points with a golden halo represent tows during lunar days 14-18.

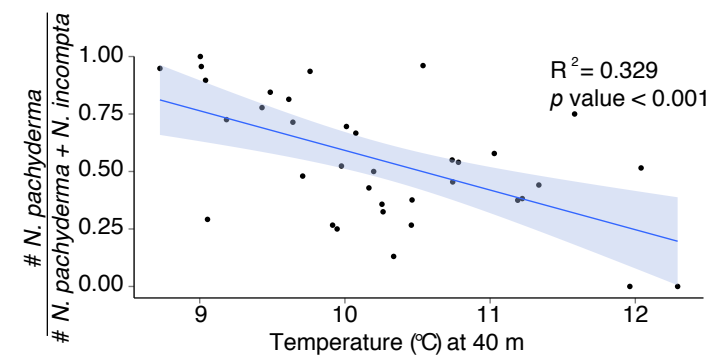

Figure 6. Ratio of $N$. pachyderma to $N$. pachyderma and $N$. incompta at $40 \mathrm{~m}$ depth with $95 \%$ confidence envelopes.

\subsection{Neogloboquadrina coiling direction}

Coiling direction for Neogloboquadrinids is recognized as an empirical proxy for sea-surface temperature in the sedimentary record (Ericson, 1959; Bandy, 1960; Kennett, 1968; Bé and Tolderlund, 1971; Vella, 1974; Arikawa, 1983; Reynolds and Thunell, 1986). We tested whether the relationship is consistent on shorter timescales with mixed assemblages of $N$. pachyderma (primarily sinisterly coiling) and $N$. incompta (primarily dextral coiling) (Darling et al., 2006). A very weak linear correlation with surface temperature is observed, between the ratio of $N$. pachyderma to all $N$. pachyderma and $N$. incompta $\left(r^{2}=0.09626 ; p\right.$ value $\left.=0.02\right)$. Correlations improved deeper in the water column, with a weak but notable relationship at $40 \mathrm{~m}\left(r^{2}=0.3285 ; p\right.$ value $\left.<0.001\right)$ (Fig. 7).

\section{Discussion}

\subsection{Foraminiferal seasonality}

A key finding of this study is the clear seasonality of the four most abundant species of planktic foraminifera at offshore stations along the central California shelf. Our findings highlight the importance of seasonal-scale water column shifts in dictating foraminiferal species abundances, as well as suggest which species may be most vulnerable to ocean acidification in the region. It may also act as a guide to paleoceanographers in deciphering the specific species most likely to be recording seasonal signals along the shelf. $T$. quinqueloba appears to be associated mainly with the early summer months and the beginning of upwelling season as indicated by the PFEL Upwelling Index for the relevant study years. $N$. pachyderma increased in both total number and relative abundance in the late summer months following the onset of upwelling. G. bulloides is largely confined to the winter non-upwelling season while $N$. incompta is present in all seasons. The year-round presence of $N$. incompta combined with the high summer abundance of $N$. pachyderma creates the appearance of a seasonal switch in the relative abundances of the two Neogloboquadrinids (Fig. 3). These trends are described in more detail for each of the four species below.

\subsubsection{Neogloboquadrinids}

The seasonal trade-off observed at offshore stations between $N$. pachyderma and $N$. incompta is in agreement with previous studies interpreting seasonality from the geochemistry of the two species. Sediment trap data from the western North Pacific found that $N$. incompta and $G$. bulloides reflect winter sea-surface temperature while $N$. pachyderma reflects summer (Sagawa et al., 2013). Similarly, $\mathrm{Mg} / \mathrm{Ca}$ ratios in recent fossils from the Norwegian Sea indicate that $N$. pachyderma is primarily a summer bloom species while $N$. incompta records winter conditions (Nyland et al., 2006). The close association between $G$. bulloides and $N$. incompta seen here has also been noted previously both in the water column and in coretop records (Reynolds and Thunell, 1986; Giraudeau, 1993; Ufkes et al., 1998).

The ratio of $N$. pachyderma to $N$. incompta (previously $N$. pachyderma var. sinistral and N. pachyderma var. dextral, respectively) has long been recognized to be paleoceanographically significant in marine sediments, with $N$. pachyderma associated with subpolar water masses, $N$. incompta associated with subtropical to temperate waters, and the ratio between the two acting as a proxy for sea-surface temperature (Ericson, 1959; Bandy, 1960; Kennett, 1968; Bé and Tolderlund, 1971; Vella, 1974; Arikawa, 1983; Reynolds and Thunell, 1986). The relationship observed here between coiling direction of Neogloboquadrinids and temperature is weak, at best, at the surface. The relationship is slightly stronger at $40 \mathrm{~m}$ depth (Fig. 7), with an equal ratio between 

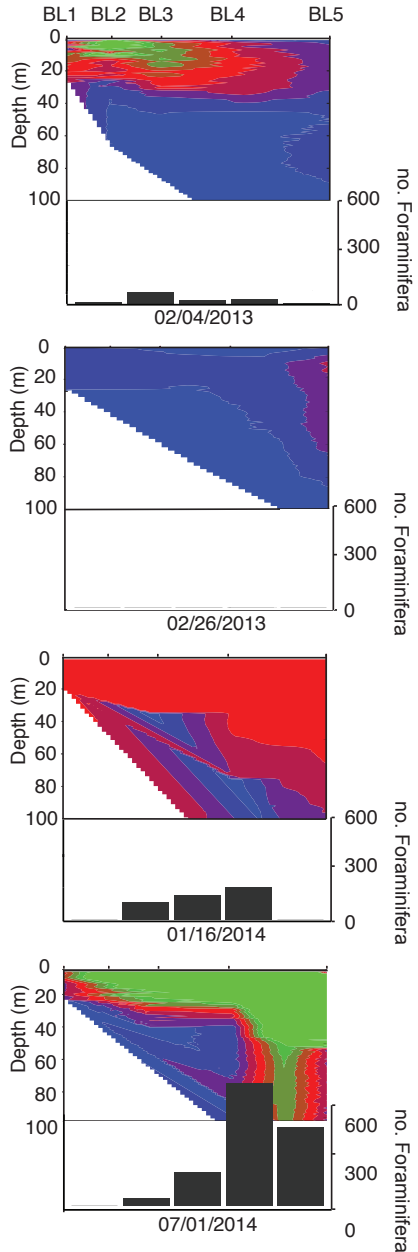

Figure 7. Water column fluorescence data and total number of foraminifera recovered at stations BL $1-5$ on 4 days of extremely low productivity. CTD data from these five stations demonstrate small-scale variability from 1 to $32 \mathrm{~km}$ offshore along the continental shelf. This is compared with the total number of foraminifera retrieved at each of these stations.

$N$. incompta and $N$. pachyderma found around $10.5^{\circ} \mathrm{C}$. This ratio can largely be explained by the year-round presence of $N$. incompta, punctuated by an increase in $N$. pachyderma in the summer along with cooler temperatures, especially in the subsurface. These findings validate on short timescales what has been seen to be empirically true over longer timescales: $N$. pachyderma is found primarily in high-latitude waters and, when occurring in temperate regions, occurs mixed with $N$. incompta, in both the water column or sediment. This pattern is suggestive of an incursion of these cooler northern waters and not solely the impact of upwelled waters in this region $\left(<10^{\circ} \mathrm{C}\right.$ conditions $)$.
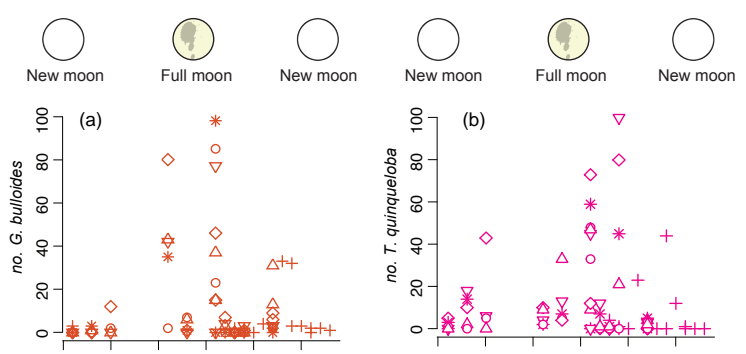

Tow Site

- BL1
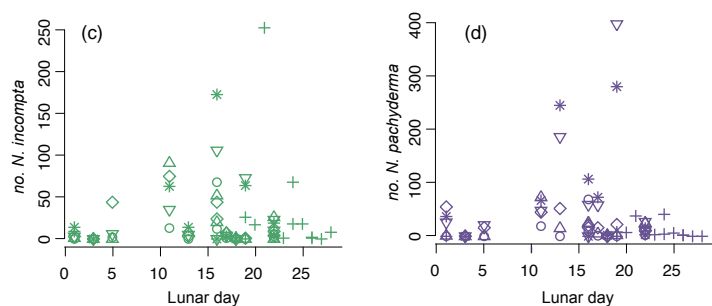

$\triangle \mathrm{BL} 2$

- BL3

$\boldsymbol{\nabla}$ BL4

* BL5

Figure 8. G. bulloides, T. quinqueloba, $N$. incompta, and N. pachyderma counts by lunar day from the new moon (day 0 ) to full moon (Day 14). Abundances are taken from integrated tows, at 25, 45, 90,120 , and $200 \mathrm{~m}$ depending on the station (see Table 1). Symbols denote tow station.

\subsubsection{Globigerina bulloides}

Globigerina bulloides has previously been associated with active upwelling in Southern California (Sautter and Thunell, 1991; Field et al., 2006) and the Arabian Sea (Peeters et al., 2002). Observations along the central California shelf are in direct contrast to this, with $G$. bulloides observed to be far more abundant during the fall/winter relaxation and storm season (Fig. 3). It is notable that in at least one previous study, G. bulloides has shown a bimodal abundance in Southern California, with one population of G. bulloides associated with winter and another population with the spring / summer upwelling season (Sutter and Thunell, 1991). Furthermore, two distinct genotypes of $G$. bulloides have been identified in Southern California, one of which is present in winter samples and was previously recognized in "subpolar" regions (Darling et al., 2003). We interpret the G. bulloides observed along the central California coast as connected to this "subpolar"/winter population, accounting for the differences in seasonal abundance seen at our northern site compared to Southern California.

\subsubsection{Spatial dynamics}

Nearshore stations BL1 and BL2 are shoreward from the primary band of coastal upwelling (Huyer, 1983) and show less seasonality in species abundances with the exception of G. bulloides, which is more abundant in the fall and winter nearshore as well as offshore. Although non-spinose forms are also occasionally present at both nearshore sites, they do not show the seasonality that they do at offshore sites (Fig. 4). Some of the differences seen in the fauna at BL1 and BL2 
compared to offshore stations may be due to shallower tow depths at these sites ( 25 and $45 \mathrm{~m}$, respectively) and therefore a bias in favor of species living closer to the surface, which may include $G$. bulloides. However, shallow tows conducted at BL4 and BL5 confirm that all four species considered here are present in the upper water column $(<30 \mathrm{~m})$ at these sites, so depth alone cannot completely account for the nearshore/offshore difference in foraminiferal abundances. Nearshore stations may be sheltered from larger-scale transitions in source water that happen over most of the shelf and be more impacted by terrestrial processes.

Short-term spatial dynamics were also observed to impact foraminiferal abundance. On days when overall productivity was low, abundances of all foraminifera species were higher at sites with higher fluorescence (indicating higher biomass and suggesting higher primary productivity). Especially low fluorescence (near-surface fluorescence $<2$ ) was observed on collection days 4 February 2013, 16 January 2014, 1 July 2014, and 26 February 2013. On these days, foraminifera were recovered in much greater numbers at stations associated with peak fluorescence regardless of where along the transect the station was located (Fig. 8). No foraminifera were recovered at very low-productivity stations BL1 and BL5 on 16 January 2014 or at BL1 on 1 July 2014, while other sites yielded $>100$ individuals. On 4 February 2013, BL2 was associated with the only observation of surface fluorescence $>10$ and yielded more foraminifera than all other sites combined. Fluorescence was low at all sites on 26 February 2013 and no foraminifera were recovered from these tows (Fig. 8). These data indicate that phytoplankton productivity may ultimately be a limiting factor for all species. On days with higher measured fluorescence (productivity), the dominant spatial trend was towards higher abundances further offshore regardless of where peak productivity was observed.

\subsubsection{Foraminifera in reduced $\mathrm{pH}$ waters}

Upwelling associated waters with low $\Omega_{\mathrm{Ca}}$ were observed on multiple occasions during plankton tows. Foraminifera are widely thought to be susceptible to ocean acidification (i.e., Barker and Elderfield, 2002; Manno et al., 2012; Moy et al., 2009; Orr et al., 2005), although this susceptibility may not always manifest through a reduction in shell weight in openocean conditions (i.e., Beer et al., 2010; Aldridge et al., 2012; Weinkauf et al., 2016). The association of multiple species of foraminifera already living at $\Omega_{\mathrm{Ca}}<1$ or very low $\Omega_{\mathrm{Ca}}(<1.5)$ waters is notable. In particular, more than a quarter $(26 \%)$ of all observed $N$. pachyderma, with its strong upwelling association, was found to occur in a water column with $\Omega_{\mathrm{Ca}}<1$ in the upper $160 \mathrm{~m}$. Culture studies with this species have indicated a decrease in shell weight associated with low $\Omega_{\mathrm{Ca}}$ well within the range of those that $N$. pachyderma was found in during upwelling season, indicating the potential to impact carbonate flux in areas where this organism is an important calcifier (Manno et al., 2012). If $N$. pachyderma is already living near its $\Omega_{\mathrm{Ca}}$ tolerance, this species may be exceptionally vulnerable to a continued increase in ocean acidification in this region. However, it is possible that upwelling-adapted $N$. pachyderma may prove to be an example of a calcifying plankton able to tolerate undersaturated waters.

\subsection{Causes of seasonality and fluctuations in abundance}

Seasonality has previously been identified in temperate regions globally for all four of the species addressed here (Jonkers and Kucera, 2015). One important mechanism contributing to the seasonal progression of foraminifera species along the shelf in central California is the alternation between the direction of net water transport between upwelling and non-upwelling seasons. This phenomenon would account for the occurrence of $G$. bulloides in greater numbers outside of upwelling season when net poleward water transport is expected (Kaplan and Largier, 2006). Similarly, the influx of subpolar associated $N$. pachyderma could be due to this species being carried into the region during the southward transport of water that occurs during upwelling season (Kaplan and Largier, 2006). This is in slight contrast to the hypothesis of $N$. pachyderma dormancy outside of upwelling season suggested in the Arabian Sea (Ivanova et al., 1999), since in the California Current as well as on the Namibian margin there is some synchronicity between the preferred seasonality of $N$. pachyderma and greater transport into the region from high-latitude waters (Ukfes and Zachariasse, 1993). An alternation between the foraminiferal fauna of source waters additionally offers an explanation for the seasonal absence and reappearance of both $N$. pachyderma and G. bulloides. N. incompta, found year-round in the study region, may be present in both water masses.

In addition to the broad oscillation of source waters, higher counts of each species are associated with some specific water column characteristics. In most cases, species abundances could not be linked strongly to single environmental parameters, but rather a suite of hydrographic and temporal variables were required to account for faunal assemblages. For some species, particular variables can be identified through pairwise correlation as having a significant effect on abundance (Fig. S2 in the Supplement). In G. bulloides, higher abundance correlates with higher water temperatures throughout the water column. In N. pachyderma, higher abundances are associated with higher fluorescence and thus enhanced primary production. For $N$. incompta, counts seem to loosely correlate with higher $\mathrm{O}_{2}$ and lower salinities, while T. quinqueloba is not clearly correlated with any single measured parameter (Fig. S2).

A CCA shows the relative abundances of $G$. bulloides, $N$. incompta, and $N$. pachyderma to be dependent upon environmental variables strongly associated with coastal upwelling conditions (Fig. 6). However, the directions of those 
associations vary. N. pachyderma and, to a lesser extent, $T$. quinqueloba seem to be associated with upwelling-like water conditions. Sediment trap time series have previously linked T. quinqueloba to productivity in the North Atlantic (Chapman, 2010), which could explain the association of this species with the higher-productivity season, although it is not directly associated with shifts in productivity as is $N$. pachyderma. G. bulloides, however, is negatively associated with upwelling-like water conditions and more associated with warmer waters and higher DO levels seen outside of upwelling season. $N$. incompta relative abundances also increase outside of upwelling season, although in this case relativity may be key, especially with regards to N. pachyderma (see Sect. 4.1.1). This outcome is supported by total counts, which indicate that this species is the only one clearly present at the tow sites year-round.

\subsubsection{Lunar periodicity}

Abundances of G. bulloides, T. quinqueloba, N. incompta, and $N$. pachyderma all display an abundance cycle with a 28-day period that appears to coincide with the lunar cycle (Fig. 9). Peak counts for each species occur within 7 days of the full moon, before dropping off before the new moon (Fig. 8). This trend offers further evidence that planktic foraminifera reproduce on a lunar cycle (Spindler et al., 1979; Bijma et al., 1990, 1994; Schiebel et al., 1997; Jonkers et al., 2015; Venancio et al., 2016; Erez et al., 1990). The peak abundance for $G$. bulloides occurs before that in the other species, starting 3 days before the full moon and remaining high until 4 days after the full moon. Abundances in $N$. pachyderma and $N$. incompta begin to increase around the same time, but high abundances in these species continue until 5 and 7 days after the full moon, respectively. Whether the observed offsets in peak abundance around the full moon represent inter-species differences in reproductive timing or are an artefact of sampling against a background of strong seasonality in a highly variable environment cannot be resolved from this dataset, even though sampling days surrounding the full moon occurred across seasons (Fig. 5).

\subsection{Application to the fossil record}

The presence of seasonally distinct faunas along the central California margin can be used in increasing the resolution of paleoceanographic and paleoecological records, as different species clearly represent different states of the seasonal upwelling regime. Single-species geochemical records are likely to show a strong bias towards either upwelled or nonupwelled water masses and, therefore, could potentially be harnessed as a record of changes in upwelling intensity and associated water chemistry. Our findings reaffirm a strong relationship between the dominance of $N$. pachyderma in conditions favorable to upwelling. This pattern has been noted along the African margin (Giraudeau, 1993), in the Ara- bian Sea (Ivanova et al., 1999), and on the Namibian margin (Ufkes and Zachariasse, 1993). It remains possible that other genotypes of $N$. pachyderma have distinct and ecological preferences particularly those associated with the Arctic and Antarctic (Darling et al., 2006, 2007). As our record is based on discrete tows and not a continuous record, the percent composition of species cannot be directly translated into a sediment flux or to what would be preserved in aggregate in the fossil record. However, the upwelling season bloom of $N$. pachyderma seen here is strong enough that this signal would likely dominate the annual assemblages, although the vast majority of $N$. pachyderma ( $81 \%$ of those seen in tows) occur between July and November.

Globigerina bulloides has been associated with upwelling at other sites globally (Sautter and Thunell, 1991; Peeters et al., 2002; Field et al., 2006) and even used as an upwelling indicator in the fossil record (e.g., Naidu, 1990; Kroon et al., 1991; Anderson and Prell, 1993; Naidu and Malmgren, 1996). However, within our study region, this species was present almost exclusively outside of upwelling season. The majority $(88 \%)$ of the $G$. bulloides seen in our samples was observed between November and February. CCA supports these observations in indicating that the relative abundance of this species is negatively associated with upwelling-like conditions in the region. This situation contrasts with findings in Southern California and the Oman Margin (Peeters et al., 2002; Field et al., 2006), highlighting the importance of using regionally specific associations where possible when interpreting planktic assemblages in the sediment record.

\section{Conclusions}

Surveys of planktic foraminifera retrieved from plankton tows both confirm and contrast with findings of studies in analogous regions. Along the north-central California shelf there is a clear association between upwelling and N. pachyderma, which experiences a summer bloom and increases in relative abundance, as seen at other sites. This summer population of $N$. pachyderma appears to routinely experience low $\Omega_{\mathrm{Ca}}$ waters, conditions that are predicted to increase in the near future. $N$. pachyderma associations with upwelling and low temperatures are also reflected in the empirical relationship between Neogloboquadrina coiling direction, seen previously in the sediment record, with a switch in dominance between $N$. incompta and N. pachyderma at $10.5^{\circ}$. G. bulloides, however, is associated in our study with non-upwelled waters, in contrast to populations in Southern California and other upwelling regions. All species showed a lunar periodicity in their abundances, evidence of lunar timed reproduction. This study highlights the wealth of information on seasonalscale processes that is contained within foraminiferal shells. To access this information, however, it is of great importance to ground interpretations of foraminiferal proxies in species and regional ecology to the greatest extent possible. 


\section{Data availability}

All of the foraminiferal abundance data will be included as a supplement. Oceanographic data are available on request from BOON (Bodega Marine Laboratory) and Point Blue (http://www.pointblue.org/datasharing).

\section{The Supplement related to this article is available online at doi:10.5194/bg-13-5139-2016-supplement.}

Acknowledgements. We would like to thank E. Sanford, H. J. Spero, M. Elliot, and three anonymous reviewers for feedback on this manuscript. We are additionally grateful to A. Ninokowa, B. O'Donnell, and E. Rivest for their help in the lab and the field. Support was provided by UC Multicampus Research Programs \& Initiatives (T. M. Hill and B. P. Gaylord), and NSF (T. M. Hill; OCE 1444451 and OCE 1261519). This work was in part conducted by the Applied California Current Ecosystem Studies (ACCESS, www.accessoceans.org) partnership, an ongoing collaboration between Point Blue Conservation Science and the Cordell Bank and Gulf of the Farallones National Marine Sanctuaries to support marine wildlife conservation and healthy ecosystems in northern and central California. We thank the Boring Family Foundation, Faucett Catalyst Fund, Hellman Family Foundation, Moore Family Foundation, and the many Point Blue donors who have helped fund ACCESS work over the years. This is a contribution of Bodega Marine Laboratory and Point Blue Conservation Science (no. 2050).

Edited by: M. Kienast

Reviewed by: three anonymous referees

\section{References}

Aldridge, D., Beer, C. J., and Purdie, D. A.: Calcification in the planktonic foraminifera Globigerina bulloides linked to phosphate concentrations in surface waters of the North Atlantic Ocean, Biogeosciences, 9, 1725-1739, doi:10.5194/bg-9-17252012, 2012.

Anderson, D. M. and Prell, W. L.: A $300 \mathrm{kyr}$ record of upwelling off Oman during the late Quaternary: evidence of the Asian southwest monsoon, Paleoceanography, 8, 193-208, 1993.

Arikawa, R.: Distribution and Taxonomy of Globigerina pachyderma (Ehrenberg) off the Sanriku Coast, Northeast Honshu, Japan: The science reports of the Tohoku University, Geology, 53, 103-120, 1983.

Bandy, O. L.: The geologic significance of coiling ratios in the foraminifer Globigerina pachyderma (Ehrenberg) [California], J. Paleontol., 34, 671-681, 1960.

Bakun, A.: Global Climate Change and Intensification of Coastal Ocean Upwelling, Science, 247, 198-201, 1990.

Barker, S. and Elderfield, H.: Foraminiferal calcification response to glacial-interglacial changes in atmospheric $\mathrm{CO}_{2}$, Science, 297 , 833-836, 2002.
Beaufort, L., Probert, I., de Garidel-Thoron, T., Bendif, E., RuizPino, D., Metzl, N., Goyet, C., Buchet, N., Coupel, P., and Grelaud, M.: Sensitivity of coccolithophores to carbonate chemistry and ocean acidification, Nature, 476, 80-83, 2011.

Bednaršek, N., Feely, R., Reum, J., Peterson, B., Menkel, J., Alin, S., and Hales, B.: Limacina helicina shell dissolution as an indicator of declining habitat suitability owing to ocean acidification in the California Current Ecosystem, P. R. Soc. Lond. B, 281, 20140123, doi:10.1098/rspb.2014.0123, 2014.

Bé, A., and Tolderlund, D.: Distribution and ecology of living planktonic foraminifera in surface waters of the Atlantic and Indian Oceans, The micropaleontology of oceans, edited by: Funnell, B. M., and Riedel, W. R., Cambridge Press, 105-149, 1971.

Beer, C. J., Schiebel, R., and Wilson, P. A.: Testing planktic foraminiferal shell weight as a surface water $\left[\mathrm{CO}_{3}^{2-}\right]$ proxy using plankton net samples, Geology, 38, 103-106, doi:10.1130/G30150, 2010.

Berger, W. H.: Planktonic Foraminifera: selective solution and paleoclimatic interpretation, Deep-Sea Res., 15, 31-43, 1968.

Bijma, J., Erez, J., and Hemleben, C.: Lunar and semi-lunar reproductive cycles in some spinose planktonic foraminifers, J. Foramin. Res., 20, 117-127, 1990.

Bijma, J., Hemleben, C., and Wellnitz, K.: Lunar-influenced carbonate flux of the planktic foraminifer Globigerinoides sacculifer (Brady) from the central Red Sea, Deep-Sea Res. Pt. 1, 41, 511530, 1994.

Botsford, L. W., Lawrence, C. A., Dever, E. P., Hastings, A., and Largier, J.: Effects of variable winds on biological productivity on continental shelves in coastal upwelling systems, Deep-Sea Res. Pt. 2, 53, 3116-3140, 2006.

Busch, D. S., Maher, M., Thibodeau, P., and McElhany, P.; Shell Condition and Survival of Puget Sound Pteropods Are Impaired by Ocean Acidification Conditions, PLoS ONE, 9, e105884, doi:10.1371/journal.pone.0105884, 2014.

Chapman, M. R.: Seasonal production patterns of planktonic foraminifera in the NE Atlantic Ocean, Implications for paleotemperature and hydrographic reconstructions, Paleoceanography, 25, PA1101, doi:10.1029/2008PA001708, 2010.

Darling, K. F., Kucera, M., Wade, C. M., von Langen, P., and Pak, D.: Seasonal distribution of genetic types of planktonic foraminifer morphospecies in the Santa Barbara Channel and its paleoceanographic implications, Paleoceanography, 18, 1032, doi:10.1029/2001PA000723, 2003.

Darling, K. F., Kucera, M., Kroon, D., and Wade, C. M.: A resolution for the coiling direction paradox in Neogloboquadrina pachyderma, Paleoceanography, 21, PA2011, doi:10.1029/2005PA001189, 2006.

Darling, K. F., Kucera, M., and Christopher, M. W.: Global molecular phylogeography reveals persistent Arctic circumpolar isolation in a marine planktonic protist, P. Natl. Acad. Sci. USA, 104, 5002-2007, 2007.

Dickson, A. G., Sabine, C. L., and Christian, J. R.: SOP 6b: Determination of the $\mathrm{pH}$ of sea water using the indicator dye $\mathrm{m}$-cresol purple, Guide to best practices for ocean $\mathrm{CO}_{2}$ measurements, 2007.

Dugdale, R. C., Wilkerson, F. P., Hogue, V. E., and Marchi, A.: Nutrient controls on new production in the Bodega Bay, California, coastal upwelling plume, Deep-Sea Res. Pt. 2, 53, 3049-3062, 2006. 
Eguchi, N. O., Ujiié, H., Kawahata, H., and Taira, A.,: Seasonal variations in planktonic foraminifera at three sediment traps in the Subarctic, Transition and Subtropical zones of the central North Pacific Ocean, Mar. Micropaleontol., 48, 149-163, 2003.

Erez, J., Almogi-Labin, A., and Avraham, S.: On the life history of planktonic foraminifera: Lunar reproduction cycle in Globigerinoides sacculifer (Brady), Paleoceanography, 6, 295-306, 1991.

Ericson, D. B.: Coiling Direction of Globigerina pachyderma as a Climatic Index, Science, 130, 219-220, 1959.

Feely, R. A., Sabine, C. L., Hernandez-Ayon, J. M., Ianson, D., and Hales, B.: Evidence for Upwelling of Corrosive "Acidified" Water onto the Continental Shelf, Science, 320, 1490-1492, 2008.

Field, D. B., Baumgartner, T. R., Charles, C. D., Ferreira-Bartrina, V., and Ohman, M. D.: Planktonic Foraminifera of the California Current Reflect 20th-Century Warming, Science, 311, 63-66, 2006.

García-Reyes, M. and Largier, J. L.: Seasonality of coastal upwelling off central and northern California: New insights, including temporal and spatial variability, J. Geophys. Res., 117, 2012.

García-Reyes, M., Largier, J. L., and Sydeman, W. J.: Synopticscale upwelling indices and predictions of phyto-and zooplankton populations, Prog. Oceanogr., 120, 177-188, 2014.

Giraudeau, J.: Planktonic foraminiferal assemblages in surface sediments from the southwest African continental margin, Mar. Geol., 110, 47-62, 1993.

Gruber, N., Hauri, C., Lachkar, Z., Loher, D., Frölicher, T. L., and Plattner, G.-K.: Rapid Progression of Ocean Acidification in the California Current System, Science, 337, 220-223, 2012.

Harris, K. E., DeGrandpre, M. D., and Hales, B.: Aragonite saturation state dynamics in a coastal upwelling zone, Geophys. Res. Lett., 40, 2720-2725, 2013.

Hauri, C., Gruber, N., Vogt, M., Doney, S. C., Feely, R. A., Lachkar, Z., Leinweber, A., McDonnell, A. M. P., Munnich, M., and Plattner, G.-K.: Spatiotemporal variability and long-term trends of ocean acidification in the California Current System, Biogeosciences, 10, 193-216, doi:10.5194/bg-10-193-2013, 2013.

Hickey, B. M.: The California current system-hypotheses and facts, Prog. Oceanogr., 8, 191-279, 1979.

Hofmann, G. E., Barry, J. P., Edmunds, P. J., Gates, R. D., Hutchins, D. A., Klinger, T., and Sewell, M. A.: The effect of ocean acidification on calcifying organisms in marine ecosystems: an organism-to-ecosystem perspective, Annu. Rev. Ecol. Evol. S., 41, 127-147, 2010.

Huyer, A.: Coastal upwelling in the California current system, Prog. Oceanogr., 12, 259-284, 1983.

Iglesias-Rodriguez, M. D., Halloran, P. R., Rickaby, R. E., Hall, I. R., Colmenero-Hidalgo, E., Gittins, J. R., Green, D. R., Tyrrell, T., Gibbs, S. J., and von Dassow, P.: Phytoplankton calcification in a high- $\mathrm{CO}_{2}$ world, Science, 320, 336-340, 2008.

Ishikawa, S. and Oda, M.: Reconstruction of Indian monsoon variability over the past 230,000 years: Planktic foraminiferal evidence from the NW Arabian Sea open-ocean upwelling area, Mar. Micropaleontol., 63, 143-154, 2007.

Ivanova, E. M., Conan, S. M.-H., Peeters, F. J. C., and Troelstra, S. R.: Living Neogloboquadrina pachyderma sin and its distribution in the sediments from Oman and Somalia upwelling areas, Mar. Micropaleontol., 36, 91-107, 1999.
Jonkers, L. and Kucera, M.: Global analysis of seasonality in the shell flux of extant planktonic Foraminifera, Biogeosciences, 12, 2207-2226, doi:10.5194/bg-12-2207-2015, 2015.

Jonkers, L., Reynolds, C. E., Richey, J., and Hall, I. R.: Lunar periodicity in the shell flux of planktonic foraminifera in the Gulf of Mexico, Biogeosciences, 12, 3061-3070, doi:10.5194/bg-123061-2015, 2015.

Kaplan, D. M. and Largier, J. L.: HF radar-derived origin and destination of surface waters off Bodega Bay, California, Deep-Sea Res. Pt. 2, 53, 2906-2930, 2006.

Kennett, J. P.: Latitudinal Variation in Globigerina pachyderma (Ehrenberg) in Surface Sediments of the Southwest Pacific Ocean, Micropaleontology, 14, 305-318, 1968.

Kincaid, E., Thunell, R. C., Le, J., Lange, C. B., Weinheimer, A. L., and Reid, F. M. H.: Planktonic foraminiferal fluxes in the Santa Barbara Basin: response to seasonal and interannual hydrographic changes, Deep-Sea Res. Pt. 2, 47, 1157-1176, 2000.

Kroon, D., Steens, T. N. F., and Troelstra, S. R.: Onset of monsoonal related upwelling in the western Arabian Sea as revealed by planktonic foraminifers, in: Porceedings Scientific Results, edited by: Prell, W. L., Niitsuma, N., Emeis, K. C., and Meters, P., ODP 117, College Station (Ocean Drilling Program), 257264, 1991.

Langer, G., Geisen, M., Baumann, K. H., Kläs, J., Riebesell, U., Thoms, S., and Young, J. R.: Species-specific responses of calcifying algae to changing seawater carbonate chemistry, Geochem. Geophy. Geosy., 7, Q09006, doi:10.1029/2005GC001227, 2006.

Largier, J. L., Lawrence, C. A., Roughan, M., Kaplan, D. M., Dever, E. P., Dorman, C. E., Kudela, R. M., Bollens, S. M, Wilerson, F. P., Dugdale, R. C., Botsford, L. W., Garfield, N., Kuebel Cervantes, B., and Koračin, D.: WEST: A northern California study of the role of wind-driven transport in the productivity of coastal plankton communities, Deep-Sea Res. Pt. 2, 53, 2833 2849, 2006.

Lynn, R. J. and Simpson, J. J.: The California Current system: The seasonal variability of its physical characteristics, J. Geophys. Res., 92, 12947-12966, 1987.

Manno, C., Morata, N., and Bellerby, R.: Effect of ocean acidification and temperature increase on the planktonic foraminifer Neogloboquadrina pachyderma (sinistral), Polar Biol., 35, 13111319, 2012.

Marchant, M., Hebbeln, D., and Wefer, G.: Seasonal flux patterns of planktic foraminifera in the Peru-Chile current, Deep-Sea Res. Pt. 1, 45, 1161-1185, 1998.

McIntyre, A., Ruddiman, W. F., and Jantzen, R.: Southward penetrations of the North Atlantic polar front: faunal and floral evidence of large-scale surface water mass movements over the last 225,000 years, Deep-Sea Res., 19, 61-77, 1972.

Moy, A. D., Howard, W. R., Bray, S. G., and Trull, T. W.: Reduced calcification in modern Southern Ocean planktonic foraminifera, Nat. Geosci., 2, 276-280. 2009.

Naidu, P.: Distribution of upwelling index planktonic foraminifera in the sediments of the western continental-margin of india, Oceanol. Acta, 13, 327-333, 1990.

Naidu, P. D. and Malmgren, B. A.: Monsoon upwelling effects on test size of some planktonic foraminiferal species from the Oman Margin, Arabian Sea, Paleoceanography, 10, 117-122, 1995.

Naidu, P. D. and Malmgren, B. A.: A high resolution record of late Quaternary upwelling along the Oman Margin, Arabian Sea 
based on planktonic foraminifera, Paleoceanography, 11, 129140, 1996.

Nyland, B. F., Jansen, E., Elderfield, H., and Andersson, C.: Neogloboquadrina pachyderma (dex. and sin.) $\mathrm{Mg} / \mathrm{Ca}$ and $\delta^{18} \mathrm{O}$ records from the Norwegian Sea, Geochem. Geophy. Geosy., 7, Q10P19, doi:10.1029/2005GC001055, 2006.

Oberhänsli, H., Bénier, C., Meinecke, G., Schmidt, H., Schneider, R., and Wefer, G.: Planktonic foraminifers as tracers of ocean currents in the eastern South Atlantic, Paleoceanography, 7, 607632, 1992.

Oksanen, J. F., Blanchet, G., Kindt, R., Legendre, P., Minchin, P. R., O'Hara, R. B., Simpson, G. L., Solymos, P., Stevens, M. H. H., and Wagner, H.: vegan: Community Ecology Package, R package version 2.3-5, http://CRAN.R-project.org/package=vegan, last access: July 2016.

Orr, J. C., Fabry, V. J., Aumont, O., Bopp, L., Doney, S. C., Feely, R. A., Gnanadesikan, A., Gruber, N., Ishida, A., Joos, F., Key, R. M., Lindsay, K., Maier-Reimer, E., Matear, R., Monfray, P., Mouchet, A., Najjar, R. G., Plattner, G.-K., Rodgers, K. B., Sabine, C. L., Sarmiento, J. L., Schlitzer, R., Slater, R. D., Totterdell, I. J., Weirig, M.-F., Yamanaka, Y., and Yool, A.: Anthropogenic ocean acidification over the twenty-first century and its impact on calcifying organisms, Nature, 437, 681-686, 2005.

Ortiz, J. D., Mix, A. C., and Collier, R. W.: Environmental control of living symbiotic and asymbiotic foraminifera of the California Current, Paleoceanography, 10, 987-1009, 1995.

Pak, D. K., Lea, D. W., and Kennett, J. P.: Seasonal and interannual variation in Santa Barbara Basin water temperatures observed in sediment trap foraminiferal $\mathrm{Mg} / \mathrm{Ca}$, Geochem. Geophy. Geosy., 5, Q12008, doi:10.1029/2004GC000760, 2004.

Peeters, F. J. C., Brummer, G.-J. A., and Ganssen, G.: The effect of upwelling on the distribution and stable isotope composition of Globigerina bulloides and Globigerinoides ruber (planktic foraminifera) in modern surface waters of the NW Arabian Sea, Global Planet. Change, 34, 269-291, 2002.

R Core Team: A language and environment for statistical, computing, Vienna, Austria, 2013.

Reynolds, L. and Thunell, R. C.: Seasonal succession of planktonic foraminifera in the subpolar North Pacific, J. Foramin. Res., 15, 282-301, 1985.

Reynolds, L. A. and Thunell, R. C.: Seasonal production and morphologic variation of Neogloboquadrina pachyderma (Ehrenberg) in the northeast Pacific, Micropaleontology, 32, 1-18, 1986.

Robbins, L. L., Hansen, M. E., Kleypas, J. A., and Meylan, S. C.: $\mathrm{CO}_{2}$ calc - A user- friendly seawater carbon calculator for Windows, Max OS X, and iOS (iPhone), US Geological Survey Open-File Report, 2010-1280, 2010.

Sagawa, T., Kuroyanagi, A., Irino, T., Kuwae, M., and Kawahata, H.: Seasonal variations in planktonic foraminiferal flux and oxygen isotopic composition in the western North Pacific: Implications for paleoceanographic reconstruction, Mar. Micropaleontol., 100, 11-20, 2013.

Salgueiro, E., Voelker, A., Abrantes, F., Meggers, H., Pflaumann, U., Lončarić, N., González-Álvarez, R., Oliveira, P., Bartels-Jónsdóttir, H. B., Moreno, J., and Wefer, G.: Planktonic foraminifera from modern sediments reflect upwelling patterns off Iberia: Insights from a regional transfer function, Mar. Micropaleontol., 66, 135-164, 2008.
Sautter, L. R. and Thunell, R. C.: Planktonic foraminiferal response to upwelling and seasonal hydrographic conditions; sediment trap results from San Pedro Basin, Southern California Bight, J. Foramin. Res., 21, 347-363, 1991.

Schiebel, R., Bijma, J., and Hemleben, C.: Population dynamics of the planktic foraminifer Globigerina bulloides from the eastern North Atlantic, Deep-Sea Res. Pt. 1, 44, 1701-1713, 1997.

Spindler, M., Hemleben, C., Bayer, U., Be, A. W. H., and Anderson, O.R.: Lunar Periodicity of Reproduction in the Planktonic Foraminifer Hastigerina pelagica, Mar. Ecol.-Prog. Ser., 1, 6164, 1979.

Sydeman, W. J., García-Reyes, M., Schoeman, D. S., Rykaczewski, R. R., Thompson, S. A., Black, B. A., and Bograd, S. J.: Climate change and wind intensification in coastal upwelling ecosystems, Science, 345, 77-80, 2014.

Takahashi, K. and Be, A. W. H.,: Planktonic foraminifera: factors controlling sinking speeds, Deep-Sea Res., 31, 1477-1500, 1984.

Thiede, J.: Distribution of foraminifera in surface waters of a coastal upwelling area, Nature, 253, 712-714, 1975.

Thunell, R. and Sautter, L. R.: Planktonic foraminiferal faunal and stable isotopic indices of upwelling: a sediment trap study in the San Pedro Basin, Southern California Bight, Geol. Soc. Lond., Special Publications, 64, 77-91, 1992.

Thunell, R. C. and Honjo, S.: Seasonal and interannual changes in planktonic foraminiferal production in the North Pacific, Nature, 328, 335-337, 1987.

Thunell, R. C. and Reynolds, L. A.: Sedimentation of Planktonic Foraminifera: Seasonal Changes in Species Flux in the Panama Basin, Micropaleontology, 30, 243-262, 1984.

Thunell, R. C., Curry, W. B., and Honjo, S.: Seasonal variation in the flux of planktonic foraminifera: time series sediment trap results from the Panama Basin, Earth Planet Sc. Lett., 64, 44-55, 1983.

Ukfes, E. and Zachariasse, W.-J.: Origin of Coiling Differences in Living Neogloboquadrinids in the Walvis Bay Region, off Namibia, Southwest Africa, Micropaleontology, 39, 283-287, 1993.

Ufkes, E., Fred Jansen, J. H., and Brummer, G.-J. A.: Living planktonic foraminifera in the eastern South Atlantic during spring: Indicators of water masses, upwelling and the Congo (Zaire) River plume, Mar. Micropaleontol., 33, 27-53, 1998.

Vella, P.: Coiling Ratios of Neogloboquadrina Pachyderma (Ehrenberg): Variations in Different Size Fractions, Geol. Soc. Am. Bull., 85, 1421-1424, 1974.

Venancio, I. M., Franco, D., Belem, A. L., Mulitza, S., Siccha, M., Albuquerque, A. L. S., Schultz, M., and Kucera, M.: Planktonic foraminifera shell fluxes from a weekly resolved sediment trap record in the southwestern Atlantic: Evidence for synchronized reproduction, Mar. Micropaleontol., 125, 25-35, 2016.

Vénec-Peyré, M. T. and Caulet, J. P.: Paleoproductivity changes in the upwelling system of Socotra (Somali Basin, NW Indian Ocean) during the last 72,000 years: evidence from biological signatures, Mar. Micropaleontol., 40, 321-344, 2000.

Weinkauf, M. F. G., Kunze, J. G., Waniek, J. J., and Kucera, M.: Seasonal Variation in Shell Calcification of Planktonic Foraminifera in the NE Atlantic Reveals SpeciesSpecific Response to Temperature, Productivity, and Optimum Growth Conditions, PLOS One, 11, e0148363, doi:10.1371/journal.pone.0148363, 2016. 